\title{
PENGEMBANGAN MODEL KURIKULUM SEKOLAH INKLUSI BERDASARKAN KEBUTUHAN PERSEORANGAN ANAK DIDIK
}

\author{
Melda Fajra1), Nizwardi Jalinus²), Jalius Jama2), Oskah Dakhi3) \\ 1)Universitas Eka Sakti, Padang \\ 2)Universitas Negeri Padang \\ 3)STMIK Budidarma Medan \\ e-mail: \\ meldafajra77@gmail.com²), nizwardi@ft.unp.ac.id2) \\ jaliusjama@yahoo.co.id³), pemdakabnisel@gmail.com ${ }^{4}$ )
}

\begin{abstract}
The purpose of this study is to establish the empirical validity of the curriculum model for children with special needs (ABK). The data collection is carried out using interviews, documentation, and observation, involving teachers, students, and school principals. The data analysis technique uses descriptive qualitative. The results show that in general teachers and principals considered the curriculum model developed to be relevant and applicable, containing basic competencies that were appropriate to the ability levels of students with special needs; for mild $A B K$ who had minimal learning constraints, the number of basic competencies is less $21,1 \%$ than in the regular curriculum; whereas for $A B K$ with a moderate level of difficulty, the number of basic competencies in the new curriculum is $37,3 \%$ less than the regular curriculum, and this group of students needs maximum support from others. The guidebook for the new curriculum in general is also considered easy to understand, well-written, and the appearance is sufficient. Thus it can be used as an alternative curriculum for use by a wider audience.
\end{abstract}

Keywords: curriculum model, inclusion school, students with special needs

\begin{abstract}
Abstrak: Tujuan penelitian ini ialah untuk menetapkan validitas empiris model kurikulum untuk anak-anak dengan kebutuhan khusus (ABK). Pengumpulan data dilaksanakan melalui wawancara, dokumentasi serta observasi, melibatkan guru, murid dan kepala sekolah. Teknik analisis data menggunakan deskriptif kualitatif. Hasil penelitian menunjukkan bahwa pada umumnya guru dan kepala sekolah menilai model kurikulum yang dikembangkan sudah relevan dan dapat diterapakan, karena memuat kompetensi dasar yang sesuai dengan tingkat kemampuan siswa-siswa berkebutuhan khusus, bagi $A B K$ ringan yang mempunyai kendala minimal dalam belajar, kompetensi dasar menyusut $21,1 \%$. Sedangkan ABK dengan tingkat kesulitan sedang, kompetensi dasar dalam kurikuum menyusut $37,3 \%$, dan kelompok siswa ini membutuhka ndukungan orang lain yang lebih maksimal. Adapun buku pedoman yang dikembangkan secara umum dinilai mudah dipahami, dan dari segi fomat penulisan dan wujud sudah memadai. Dengan demikian dapat dijadikan sebagai alternatif kurikulum untuk digunakan oleh kalangan yang lebih luas.
\end{abstract}

Kata kunci: model kurikulum, sekolah inklusi, siswa berkebutuhan khusus 


\section{PENDAHULUAN}

Melalui pendidikan, semua kemampuan anak peserta didik bias digali serta disempurnakan dengan maksimal, anak peserta didik yang normal ataupun yang berkelainan. Oleh karena itu anak yang mempunyai kendala belajar pada tingkatan ringan serta sedang bias dididik di sekolah umum atau regular atas kualifikasi yang ditentukan. Pendidikan inklusi ini bertujuan yaitu mengendalikan keterbatasan jumlah Sekolah Dasar Luar Biasa (SDLB) dan Sekolah Luar Biasa (SLB) yang sudah ada hanya dapat mendidik sekitar 1\% dari Anak Berkebutuhan Khusus (ABK) usia sekolah dan memperlancar tercapaian program pendidikan dasar wajib belajar bagi $A B K$ di seluruh Indonesia. Beberapa persoalan tentang ABK yaitu: a) Kurikulum yang tepat sasaran serta memadai sehingga dipakai sebagai dasar/ acuan di dalam pembelajaran; b) Keterbatasan kompetensi guru didalam mengembangkan/memodifikasi kurikulum ABK; c) Keterbatasan sarana-prasarana serta; d) Kesukaran pendidik pada penilaian pemahaman ABK. Berdasarkan permasalahan di atas, penelitian ini mempunyai tujuan untuk mengembangkan model kurikulum sekolah inklusi berdasarkan kebutuhan perseorangan siswa, serta melakukan validasi empiris kurikulum inklusi.

\section{Kajian Teori Pendidikan Inklusi}

Sekolah inklusi ialah sekolah yang memfasilitasi program pendidikan yang sesuai kebutuhan dan kompetensi tiap-tiap anak, serta pemberian dukungan dan bantuan yang dapat dilakukan oleh pendidik supaya anak didik berhasil. Sekolah inklusi juga diartikan sebagai wadah dimana setiap anak bias diterima sebagai bagian dari kelas tersebut serta saling membangun dan mendukung bersama pendidik dan teman seusianya, ataupun masyarakat lainnya supaya kebutuhan perseorangannya bias tercukupi (Stainback dan Sianback, 1990) Lebih lanjut, (Sunardi, 2005) menerangkan bahwa pendidikan inklusi memposisikan anak berkebutuhan khusus tingkat berat dan sedang, maupun ringan pada kelas reguler. Hal ini berarti bahwa terlepas dari jenis dan gradasi kekurangan siswa berkebutuhan khusus, kelas regular merupakan wadah belajar yang perlu dapat mengakomodasi ABK. Selanjutnya, (Skjorten, 2001) menjelaskan pendidikan inklusi sebagai struktur layanan bagi pendidikan yang memenuhi tujuh persyaratan, yaitu: 1) Terdapat ABK pada sekolah normal; 2) Adanya support dari masyarakat sekolah, 3) Kurikulum tidak kaku, 4) Pembelajaran beragam; 5) Memiliki pendidik kelas serta pendidik spesial; 6) Memodifikasi teknik penilaian, serta 7) Tidak menggunakan system tidak naik kelas.

Di Indonesia, sekolah inklusi telah dirintis semenjak 2003. Pada penerapannya, sekolah inklusi mengalami banyak kendala, baik yang berkaitan dengan kurikulumnya, keterbatasan kompetensi guru dalam pengembangan kurikulum khusus, kesulitan dalam penilaian kompetensi $A B K$, maupun keterbatasan sarana-prasarana (Hermanto. 2010). Pada dasarnya tiap anak pasti beda satu dan yang lain, dalam hal ketrampilan akademis ataupun non-akademis. Perbedaan peserta didik ini menjadi pertimbangan dalam pengembangan kurikulum. Kurikulum yang dikembangkan harus ada penyesuaian dengan kebutuhan ABK (Kadir, 2015). 
Dengan pengembangan model berdasarkan kebutuhan perseorangan anak didik, kurikulum pada sekolah inklusi ini diharapkan dapat menjadi masukan khususnya pada sekolah regular, serta membantu menangani kendala penerapan pendidikan inklusi di Indonesia. Kualitas proses pembelajaran mempengaruhi kualitas pendidikan atau lulusan. Kualitas proses pembelajaran dipengaruhi beberapa unsure atau komponen, yakni: 1) Input/Siswa; 2) Bahanajar/Kurikulum; 3) Tenaga pendidik atau instruktur; 4) Sarana-prasarana; 5) Dana; 6) Manajemen; serta 7) Lingkungan, seperti terlihat pada Gambar 1.

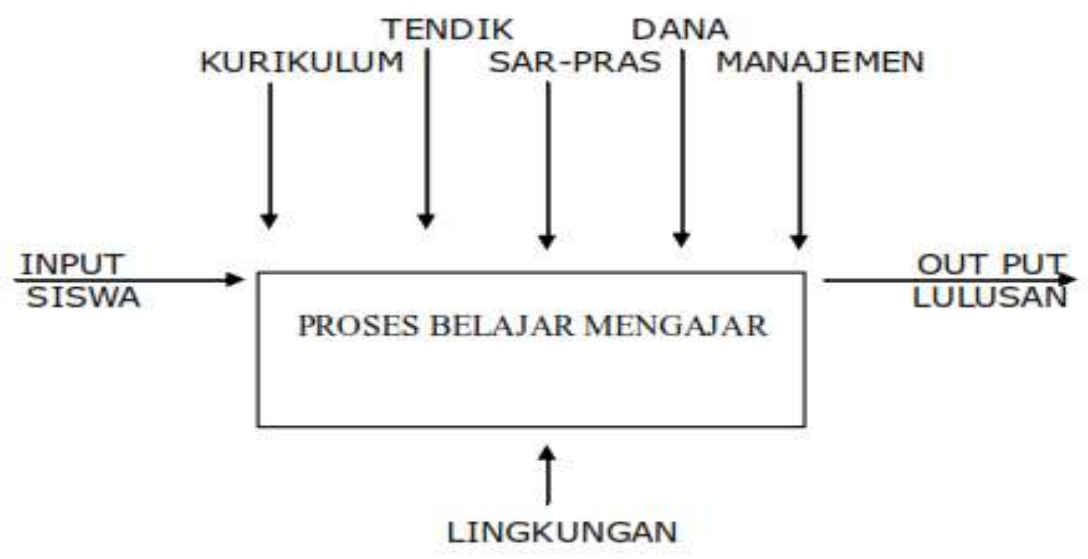

Gambar 1. Komponen yang mempengaruhi proses pembelajaran

Unsur-unsur tersebut merupakan komponen system pendidikan. Apabila salah satu komponen mengalami perubahan, maka perubahan ini akan mempengaruhi unsur lainnya. Hal ini berarti, apabila terjadi perubahan pada input siswa (anak normal dan $A B K$ ) semua komponen tersebut harus mengalami perubahan atau transformasi juga. Guru akan mengalami kesulitan dalam pelaksanaan pembelajaran yang berkualitas bila tidak dilakukannya transformasi kurikulum maupun komponen-komponen lainnya.

Pada kenyataannya, para pendidik di sekolah umum tidak dipersiapkan untuk mengajar $\mathrm{ABK}$, serta pendidikan pengajaran tentang $\mathrm{ABK}$ juga tidak tersedia bagi guru sekolah umum. Kondisi ini menimbulkan masalah ketika guru sekolah umum harus mengajar ABK di kelasnya. Kendala tersebut akan bias teratasi bilamana guru dibantu melalui penyediaan kurikulum khusus untuk ABK. Pada hakekatnya dalam dunia pendidikan, perbedaan individual menjadi bahan pertimbangan dalam melakukan perencanaan, pelaksanaan, dan penilaian pendidikan (Friend dan Bursuck, 2015).

ABK yang tidak berhasil di dalam sistem sekolah khusus tidak berarti juga akan gagal di dalam sistem belajar sekolah umum. Vaughn dan Schumm (2000) berpendapat bahwa dengan mempertimbangkan perbedaan kemampuan atau kompetensi perseorangan siswa, maka dianjurkan dilakukan pendidikan inklusi pada sekolah umum yang mengakomodasi kebutuhan ABK. Tempat belajar ABK dapat dipilih bebas diantara: classer gular atau Inklusi penuh, class regular dengan cluster, class regular dengan pull out dan class regular dengan cluster dan pull out 
serta class khusus dengan berbagai integrasi untuk mengurangi kesukaran yang dialami oleh sekolah didalam pelaksanaan pendidikan inklusi (Emawati, 2008).

Menurut pakar atau ahli pendidikan reabilitasi $A B K$ yang dapat mengikuti pendidikan inklusi di sekolah regular hanya $A B K$ dengan tingkatan hambatan ringan serta sedang. Kemudian, ABK dengan tingkatan hambatan yang berat hendaknya tetap mendapatkan fasilitas pendidikan di sekolah khusus di SDLB sertaSLB.

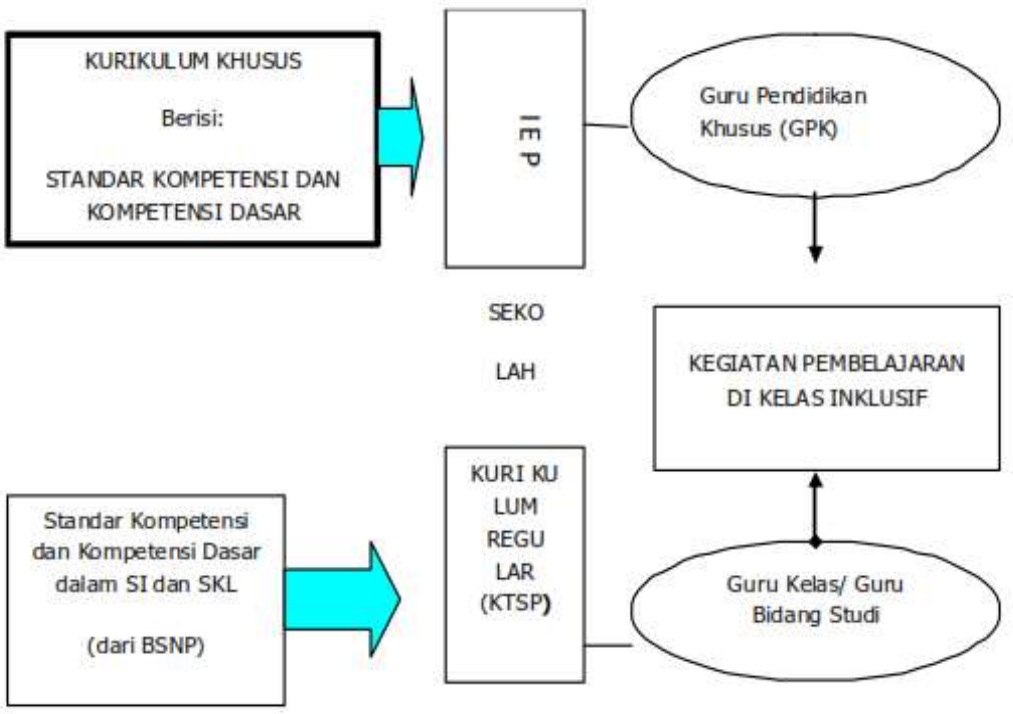

Gambar 2. Kebutuhan pengembangan kurikulum sekolah inklusi

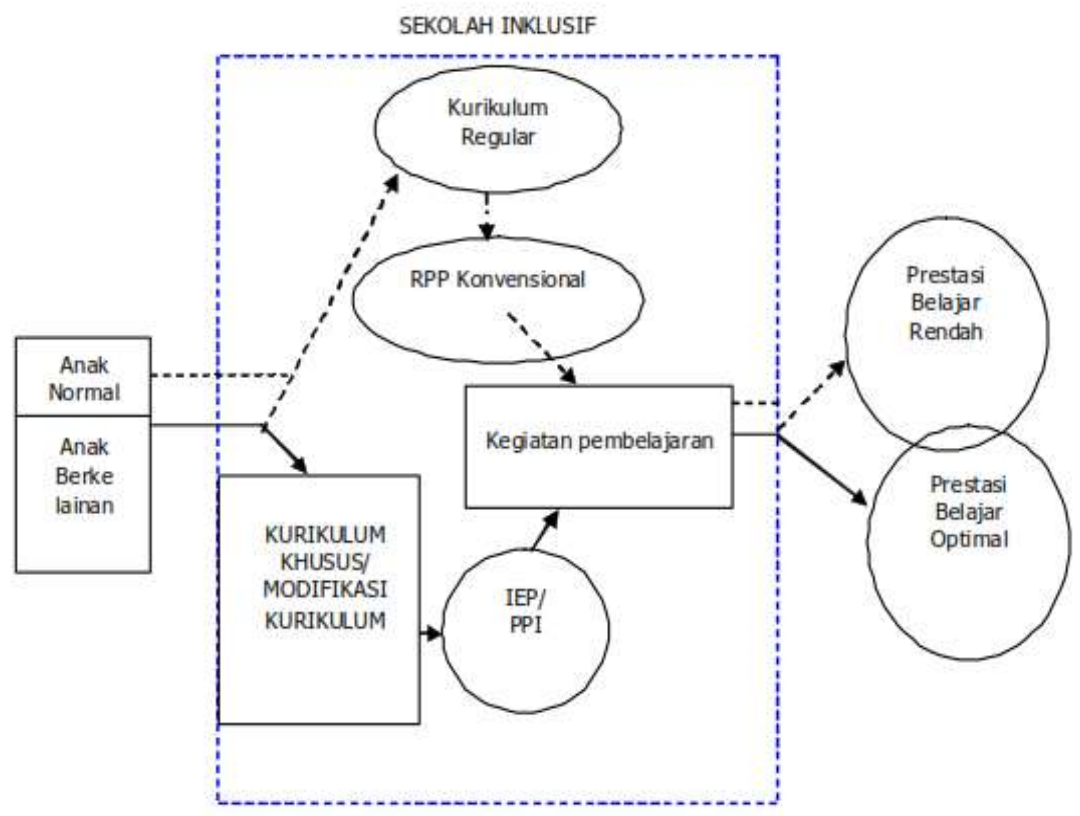

Gambar 3. Temuan penelitian/evaluasi program inklusi 
Berdasarkan Gambar 3, temuan evaluasi program inklusi mengindikasikan bahwa apabila $A B K$ di sekolah inklusi pembelajaran yang diikuti menggunakan kurikulum regular maka prestasi pembelajarnya menurun. Hal tersebut dikarenakan tidak ada pertimbangan karakteristik serta kebutuhan perseorangan anak didik ABK dalam kurikulum sekolah umum. Oleh sebab itu pada sekolah inklusi, perencanaan dan proses pembelajaran perlu ada penyesuaian berupa Individualized Educational Program (IEP) atau Program Pembelajaran Individual (PPI), dan dengan bersumber pada kurikulum transformasi yang merupakan modifikasi kurikulum "umum" dimungkinkan hasil belajar ABK akan lebiho ptimal. IEP/PPI adalah pondasi dari pendidikan untuk anak berkebutuhan khusus. IEP/PPI memberikan gambaran tentang pelayanan dan program yang akan diterima anak serta tujuan pembelajaran yang akan dicapai. IEP/PPI membutuhkan dan merupakan bentuk kerjasama tim, yang terdiri dari orang tua, guru, guru pendamping, terapis, dokter, dan psikolog.

\section{METODE}

Pendekatan penelitian ini menggunakan Research \& Development Model menurut (Borg, W R \& Gall, M D. (2003), yang terdiri dari tiga komponen atau elemen, sebagai berikut: 1) Model pengembangan; 2) Prosedur penelitian pengembangan; serta 3) Ujicoba produk pengembangan. Model pengembangan yang dipergunakan ialah model procedural dari (Sugiyono, 2017)

\section{Prosedur model pengembangan}

Prosedur atau langkah kegiatan program penelitian ini sebagai berkut:

1) Analisis model pengembangan yang dikembangkan, program yang dilaksanakan antara lain:

a) Melaksanakan penelitian pengantar untuk mengumpulkan data atau informasi seperti kajianli teratur, mengeksplorasi dokumen penilaian mengenai komponen produk yang dibutuhkan.

b) Melaksanakan perencanaan, identifikasi komponen produk yang diperlukan serta yang dikembangkan, langkah pengembangan, perencanaan ujicoba validasi ahli, perencanaan ujicoba skala kecil dan besar.

2) Kegiatan pendahuluan dalam pengembangan model ini ialah:

a) Memodifikasi kurikulum level pertama pada ABK kendala ringan.

b) Memodifikasi kurikulum level kedua pada ABK kendala sedang.

3) Ujicoba kegiatan validasi para ahli serta revisi model pertama, antara lain:

a) Melaksanakan FGD untuk mereview model awal yang telah dikembangkan.

b) Melaksanakan perubahan pertama.

4) Ujicoba empiric kegiatan lapangan skala kecil dan perubahan kedua antara lain:

a) Mensosialisasikan model transformasi kurikulum berdasarkan kebutuhan perseorangan anak didik berkebutuhan khusus tingkat I, II.

b) Pelatihan atau training penyusunan PPI atau IEP.

c) Pelatihan atau training kegiatan proses pembelajaran yang berbeda.

d) Pelatihan atau training penilaian di kelas inklusi.

e) Pelaksanaan model transformasi kurikulum level I dan II di sekolah inklusi. 
f) Evaluasi validitas empirik model transformasi kurikulum tingkat I dan II di sekolah inklusi yang akan dikembangkan.

g) Revisi atau perubahan II.

5) Ujicoba empirik skala besar serta finalisasi tahap model akhir. Dalam langkah atau kegiatan yang sama dengan yang ada ditahap ujicoba empiric lapangan skala terbatas, jumlah sekolah ujicoba serta cakupan wilayah yang lebih besar, dilanjutkan dengan kajian uji lapangan (empirik), perbaikan III, serta desiminasi (Salim dan Yusuf, 2009).

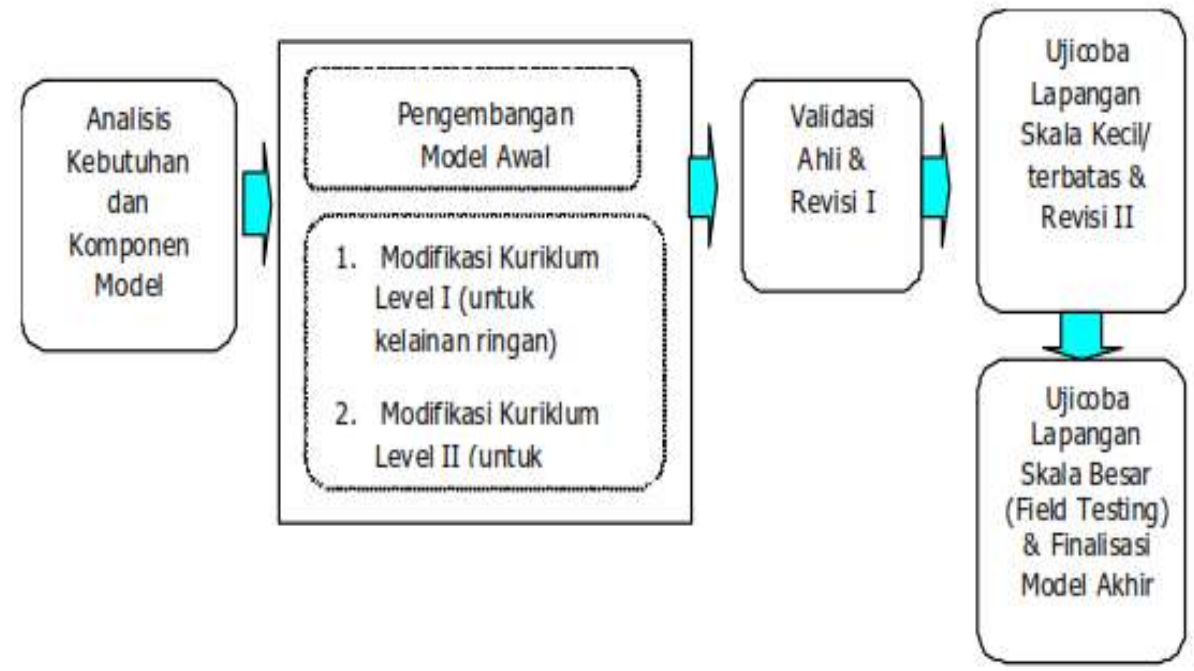

Gambar 4. Model pengembangan transformasi kurikulum sekolah inklusi

\section{Ujicoba Model}

Ujicoba model ini melalui 3 (tiga) tahap yakni dengan: a) Uji-Pakar; b) Ujicoba Empiris terbatas grup kecil; serta c) Ujicoba lapangan (field test) skala luas.
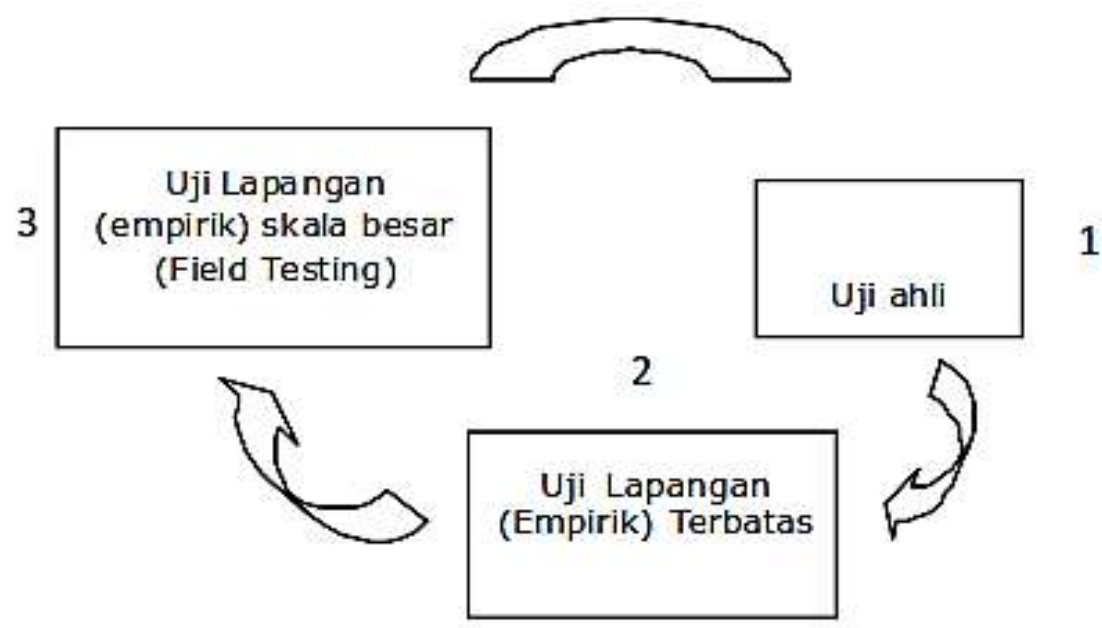

Gambar 5. Tahap ujicoba 


\section{Jenis Data}

Data dalam penelitian ini mencakup: 1) Kesesuaian pada muatan kurikulum transformasi yang sudah dikembangkan; 2) Kemudahan untuk memahami transformasi kurikulum serta petunjuk pelaksanaannya, dan 3) Ketepatan atau akurasi sistimatika kurikulumnya.

\section{Teknik Pengumpulan Data serta Instrumen}

Strategi atau teknik yang dipergunakan pada menghimpun data antara lain: metode atau strategi interview, observasi serta kuesioner.

Tabel 1. Data dan Instrumen Penelitian

\begin{tabular}{|c|c|c|c|}
\hline Data tentang & $\begin{array}{l}\text { Pengumpulan } \\
\text { Data }\end{array}$ & $\begin{array}{c}\text { Sumber } \\
\text { Data }\end{array}$ & Instrumen \\
\hline $\begin{array}{l}\text { 1. Kecermatan Isi Model } \\
\text { Modifikasi Kurikulum Level I } \\
\text { dan II Yang Dikembangkan }\end{array}$ & Interview & $\begin{array}{l}\text { Responden } \\
\text { Ahli }\end{array}$ & $\begin{array}{l}\text { Form Isian } \\
\text { Pengembangan } \\
\text { Sendiri, FGD }\end{array}$ \\
\hline $\begin{array}{l}\text { 2. Keterbacaan Model } \\
\text { Modifikasi Kurikulum Level } \\
\text { I dan II Serta Petunjuk } \\
\text { Pelaksanaan }\end{array}$ & Interview & $\begin{array}{l}\text { Responden } \\
\text { Ahli }\end{array}$ & $\begin{array}{l}\text { Form Isian } \\
\text { Pengembangan } \\
\text { Sendiri, FGD }\end{array}$ \\
\hline $\begin{array}{l}\text { 3. Ketepatan Sistematika } \\
\text { Model Modifikasi Kurikulum } \\
\text { Level I dan II }\end{array}$ & Interview & $\begin{array}{l}\text { Responden } \\
\text { Ahli }\end{array}$ & $\begin{array}{l}\text { Form Isian, Pokok } \\
\text { Interview, } \\
\text { Pengembangan } \\
\text { Sendiri, FGD }\end{array}$ \\
\hline
\end{tabular}

Berdasarkan Tabel 1, ada 3 jenis responden, terdiri dari guru Sekolah Inklusi yang diminta untuk menjawab open-ended questionnaire (pertanyaan terbuka).

Sedangkan Responden Ahli adalah guru pembimbing atau Ahli yang menangani anak berkebutuhan khusus (ABK).

\section{Subyek Ujicoba}

Subyek ujicoba dilihat dari beberapa tahapan ujicoba serta karakteristik subyek seperti pada Tabel 2 .

Tabel 2. Tahap Ujicoba dan Jumlah Sampel

\begin{tabular}{|c|c|c|c|c|}
\hline $\begin{array}{l}\text { Tahapan Ujicoba } \\
\text { Awal Uji Ahli }\end{array}$ & $\begin{array}{l}\text { Jumlah } \\
\text { Sampel }\end{array}$ & $\begin{array}{l}\text { Karakteristik Sampel Ahli Kurikulum, } \\
\text { Anggota Tim BSNP, Ahli Pendidikan } \\
\text { Khusus, Kepala Sekolah Inklusi, } \\
\text { Kepala SLB, Kepala SDLB, Pejabat } \\
\text { Dinas, Pendidikan Kota/Kabupaten }\end{array}$ & $\begin{array}{l}\text { Teknik } \\
\text { Sampling } \\
\text { Purposif }\end{array}$ & $\begin{array}{l}\text { Proses Orientasi, dan } \\
\text { Hasil Ujicoba Kualitatif } \\
\text { (FGD), Kuesioner, } \\
\text { Interview, Draf Awal } \\
\text { Model Modifikasi } \\
\text { Kurikulum Level } 1 \text { dan 2, } \\
\text { Kesesuaian Substansi }\end{array}$ \\
\hline $\begin{array}{l}\text { Utama Kelompok } \\
\text { Kecil }\end{array}$ & 30 & $\begin{array}{l}\text { Penggunaan Model yang } \\
\text { Dikembangkan Pada Sekolah Inklusi }\end{array}$ & Random & $\begin{array}{l}\text { Eksperimen, Q- } \\
\text { Eksperimen, Kesesuaian } \\
\text { Model Dengan }\end{array}$ \\
\hline $\begin{array}{l}\text { Uji Lapangan } \\
\text { Operasional, } \\
\text { Tahap Akhir }\end{array}$ & 44 & $\begin{array}{l}\text { Penggunaan Model Yang } \\
\text { Sebenarnya Beberapa Sekolah } \\
\text { Inklusi di Kota Padang }\end{array}$ & Random & $\begin{array}{l}\text { Pelaksanaan Model Yang } \\
\text { SiapPakai }\end{array}$ \\
\hline
\end{tabular}




\section{Teknik Analisis Data}

Teknik analisis data dilakukan untuk menggambarkan keseluruhan data hasil penelitian yang berkaitan pada model kurikulum yang telah dimodifikasi untuk sekolah inklusi, termasuk dimensi akurasi atau ketepatan isi, keterbacaan pedoman dan keberhasilan model di dalam ujicoba.

\section{HASIL DAN PEMBAHASAN}

Model kurikulum anak inklusi yang telah ditransformasi di sini ialah muatan kurikulum yang mencakup penyesuaian standar kemampuan (SK) kompetensi dasar(KD) mata pelajaran MTK, PPKN IPA, IPS, dan B. Indonesia pada SD/MI.

Muatan kurikulum tersebut diistilahkan prototipe pedoman. Prototipenya terdiri dari: a) Prototipe penelitian acuan pedoman transformasi kurikulum tingkat pertama pada ABK ringan; b) Prototipe penelitian acuan pedoman transformasi kurikulum tingkat kedua pada ABK sedang. Pengembangan prototype dengan tujuan menelaah SK, KD menurut esens ikeilmuan, selanjutnya dilaksanakan modifikasi beberapa bagian untuk disesuaikan pada kompetensi serta kendala yang dirasakan para $A B K$ level ringan maupun sedang. Hasil kajian SK-KD untuk ABK ringan ditampilkan pada Tabel 3 .

Tabel 3. Ringkasan Hasil Modifikasi SK-KD Untuk Anak dengan Hambatan Belajar Ringan

\begin{tabular}{llcc}
\hline \multicolumn{1}{c}{ Mata Pelajaran } & SK - KD Lama & SK - KD Modifikasi & Presentase \\
\hline 1. Matematika & SK 45 Buah & SK 45 Buah & 76,3 \\
& KD 118 Buah & KD 90 Buah & \\
2. PPKN & SK 30 Buah & SK 30 Buah & 67,3 \\
& KD 118 Buah & KD 80 Buah & \\
3. IPA & SK 15 Buah & SK 15 Buah & 82,98 \\
& KD 47 Buah & KD 39 Buah & \\
4. IPS & SK 26 Buah & SK 26 Buah & \multirow{2}{*}{92} \\
& KD 50 Buah & KD 46 Buah & \\
5. Bahasa Indonesia & SK 38 Buah & SK 38 Buah & 75,8 \\
& KD 120 Buah & KD 91 Buah & \\
\hline
\end{tabular}

Hasil kajian SK-KD untuk ABK sedang ditampilkan pada Tabel 4.

Tabel 4. Ringkasan Hasil Modifikasi SK-KD untuk Anak dengan Hambatan Belajar Sedang

\begin{tabular}{lcrlc}
\hline Mata Pelajaran & SK - KD Lama & SK - KD Modifikasi & Presentase \\
\hline 1. Matematika & SK 45 Buah & SK 45 Buah & 62,7 \\
& KD 118 Buah & KD 74 Buah & \\
2. PPKN & SK 30 Buah & SK 30 Buah & 67,8 \\
& KD 118 Buah & KD 80 Buah & \\
3. IPA & SK 15 Buah & SK 15 Buah & 48,9 \\
& KD 47 Buah & KD 23 Buah & \\
4. IPS & SK 26 Buah & SK 26 Buah & 66 \\
& KD 50 Buah & KD 33 Buah & \\
5. Bahasa Indonesia & SK 38 Buah & SK 38 Buah & 68,3 \\
& KD 120 Buah & KD 82 Buah & \\
\hline
\end{tabular}


Berdasarkan Tabel 3 dan 4 diketahui untuk $A B K$ ringan, $K D$ pada kurikulum regular berkurang sebesar $21,1 \%$, sedangkan untuk $A B K$ sedang, $K D$ di dalam kurikulum regular berkurang sebanyak 37,3\%. Angka tersebut diperoleh dari 100\% dikurangi rata-rata persentase pengurangan KD Kurikulum Modifikasi dari KD Kurikulum regular. Mata pelajaran bahasa Indonesia misalnya pada kelas VI bagi ABK sedang terjadi pengurangan KD 2.1 (Menyampaikan pesan/informasi yang diperoleh dari berbagai media dengan bahasa yang runtutdan komunikatif) dan KD 4.4 (Mengubah puisi ke dalam bentuk prosa dengan tetap memperhatikan maknanya), sedangkan untuk $A B K$ ringan, pengurangan pada KD 4.4 dan seterusnya. Demikian juga untuk matapelajaran matematika kelas $\mathrm{VI}$ misalnya bagi ABK sedang, terjadi pengurangan pada KD 1.3 (Menyelesaikan masalah yang melibatkan operasi hitung termasuk penggunaan akan dan pangkat), KD 3.3 (Menghitung volume prisma segitiga dan tabung, lingkaran) dan KD 5.5 (Memecahkan masalah perbandingan dan skala), sedangkan untuk ABK ringan, pengurangan pada KD 3.3 dan KD 5.5 dan seterusnya, demikian untuk kelas dan matapelajaran lainnya.

Pengurangan atau perampingan KD dengan mempertimbangkan beberapa hal yakni: A) Kemampuan atau kompetensi dasar yang dirancangkan terlampau sulit bagi $A B K$, yang mana tidak sesuai dengan standar kurikulum baku regular, contoh memodifikasi kurikulum umum yang diberlakukan untuk siswa-siswa regular dirubah tidak disesuaikan dengan kemampuan siswa berkebutuhan khusus; b) Kemampuan atau kompetensi dasar tertentu lebih sesuai pada semester atau jenjang kelas atas, serta c) Terdapat kemampuan atau kompetensi dasar khusus yang esensinya telah termasuk pada KD Inti seperti pengetahuan, sikap dan pengetahuan lainnya.

\section{Implementasi Model Kurikulum Modifikasi dan Validitas Empiris Model Modifikasi Kurikulum}

Kepala sekolah dan guru SD inklusi yang dijadikan sebagai tempat ujicoba diminta menerapkan atau mengaplikasikan kurikulum modifikasi tersebut di dalam pembelajaran anak yang berkebutuhan khusus, parameter yang dipergunakan ialah:

1) Pendidik kelas sudah:

a) Merencanakan pembelajaran perseorangan berdasarkan perubahan kurikulum.

b) Melakukan kegiatan proses pembelajaran sesuai dengan Program Pembelajaran Individual (PPI) yang telah dikembangkan.

c) Mencatatkan perkembangan anak didik.

2) Kepala sekolah sudah:

a) Memastikan rencana pembelajaran perseorangan yang disusun oleh pendidik/guru.

b) Menyaksikan atau membuktikan guru kelas telah melaksanakan proses pembelajaran berbasis sesuai Program Pembelajaran Individual (PPI).

c) Kepala sekolah sudah membuktikan kemajuan anak di dalam kegiatan sehari-harinya. 
3) Menurut pernyataan peserta didik bahwa:

a) Guru pernah member proses pembelajaran.

b) Anak didik sudah melaksanakan kegiatan proses pembelajaran (Ahmad, dkk.(2014).

Ada beberapa tolak ukur yang dipergunakan dalam menentukan keberhasilan model transformasi kurikulum ini ialah bilamana sekitar $63 \%$ kepala sekolah SD dan guru kelas menyetujui, menyepakati serta memberikan jawaban yang sesuai dengan indikator pembelajaran.

Tabel 5. Data Jumlah Rata-rata Skor Keberjalanan Model Modifikasi Kurikulum

\begin{tabular}{lrrcc}
\hline Sumber Data & Jumlah & $\begin{array}{c}\text { Jumlah } \\
\text { Skor }\end{array}$ & $\begin{array}{c}\text { Jumlah Skor } \\
\text { Maks }\end{array}$ & Rata-rata Skor \\
\hline Guru Kelas & 16 & 181 & 15 & 11,31 \\
Kepala SD & 6 & 21 & 6 & 3,50 \\
PesertaDidik & 22 & 181 & 8 & 5,62 \\
\hline \multicolumn{2}{c}{ Jumlah } & & \multicolumn{4}{c}{$20,43: 29 \times 100=70,45$} \\
\hline \multicolumn{2}{c}{$\%$}
\end{tabular}

Pada Tabel 5 jumlah skor merupakan hasil akumulasi dari masing-masing indkator implementasi kurikulum modifikasi tersebut, dimana untuk guru terdiri dari 3 indikator, kepala sekolah terdiri dari 3 indikator, dan untuk siswa terdiri dari 2 indikator. Jumlah skor maksimal ditentukan berdasarkan skor maksimal tiap indicator kriteria penilaian pada pedoman penskoran. Sedangkan rata-rata skor diperoleh dari jumlah skor dibagi dengan jumla responden. Jumlah rata-rata skor di atas diperoleh hasil wawancara kepala sekolah dan guru kelas, serta anak didik yang berkebutuhan khusus sekitar 20,43, dengan presentase fasilitas rehabilitasi sekitar $70,45 \%$. Demikian, dilihat dari segi keberhasilan model transformasi kurikulum ini yang dipergunakan di dalam penelitian ini, dapat dinyatakan bahwa keberhasilan model transformasi kurikulum untuk sekolah yang inklusi sekitar $70,45 \%$. Pemahaman kepala sekolah dan guru mengenai isi buku pedoman di sini dibagi menjadi 4 bagian, ialah sangat baik, baik, kurang baik serta tidak baik. Data atau bahan ini didapatkan berdasar pada skala penilaian yang diisi oleh kepala sekolah dan para pendidik/guru.

Hasil pengumpulan data serta analisis deskriptif diperoleh: Interpretasinya sangat baik sekitar $47 \%$, Interpretasinya yang baik sekitar 33\%, Interpretasinya kurang baik sekitar1 7\%, Interpretasinya tidak baik sekitar 3\%. Berangkat dari panduan di atas, analisis aspek validitas empiris buku pedoman didapat dari hasil berikut: a) Makna atau esensi buku pedoman: Sebesar (87,3\%) kepala sekolah dan guru telah sepakat isi esensi atau substansi buku pedoman, hanya $12,7 \%$ yang kurang sepakat; b) Keterbacaan buku pedoman: 1) Sekitar 87,3\% buku pedoman telah memakai bahasa yang benar dan baik di dalam penulisannya, sekitar $12,7 \%$ yang belum baik, 2) Sebanyak $87,3 \%$ buku pedoman sudah menggunakan atau memakai kaidah penulisan yang baik, padat, dan singkat. Sebanyak $12,7 \%$ tidak merespon pertanyaan; c) Penampilan buku pedoman.

Performa buku pedoman mencakup aspek tipe huruf, ukuran buku, konsistensi penomoran, tata letak, pewarnaan serta kesan umum performa buku pedoman. Dari hasil analisis data sebanyak $63 \%$ buku pedoman sudah memiliki 
performa yang baik, sekitar $28 \%$ belum baik, serta $9 \%$ tidak merespon pertanyaan tersebut.

Sekolah inklusi adalah wacana yang baru di dalam bidang pendidikan yang membutuhkan panduan di dalam sistem pengelolaannya, dikarenakan sekolah inklusi sebagian anak didik tersebut memiliki kompetensi yang cukup normal. Pedoman di dalam transformasi kurikulum untuk pengeloaan sekolah inklusi merupakan komponen yang dibutuhkan para pendidik, agar dapat melaksanakan penyelarasan kurikulum reguler yang disesuaikan dengan kebutuhan para didikan yang $A B K$ atau mengalami kendala belajar.

Penelitian ini menunjukkan hasil yang sesuai dengan pernyataan Suharso sebagai pakar pembaharuan atau rehabilitasi kepada ABK di Indonesia bahwa anak yang $A B K$ ringan mempunyai kendala di dalam belajar meskipun pada tingkatan minimal, ialah kurang lebih $21,1 \%$. Sedangkan untuk anak yang $A B K$ tingkat sedang, mereka membutuhkan dukungan orang lain yang lebih maksimal, karena kendalanya kurang lebih 37,3\%. Keberadaan atau eksistensi ABK di kelas inklusi juga mengharuskan guru melaksanakan transformasi strategi atau metode yang dipergunakan di dalam pembelajaran tersebut.

Metode atau strategi pembelajaran merupakan cara menggapai hasil proses pembelajaran di bawah kondisi atau situasi yang berlainan. Strategi pembelajaran tersebut dipicukan sebagai cara untuk dapat dipergunakan dalam situasi tertentu sehingga tercapai hasil proses pembelajaran yang ingin dicapai. Strategi pembelajaran dibagi menjadi tiga jenis variabel, antaralain: 1) Strategi atau metode pengorganisasian; 2) Strategi atau metode penyampaian; 3) Strategi atau metode pengelolaannya. Metode pengorganisasian proses pembelajaran di sini ialah metode atau strategi untuk mengorganisasikan isi matapelajaran yang sudah dipakai pada pembelajaran. Mengorganisasikan kepada suatu kegiatan seperti penyusunan diagram, penetapan, penataanisi, format, dan lainnya yang ekuivalen. Ada 3 strategi atau metode pembelajaran untuk anak yang berkelainan di kelas inklusi, ialah: 1) Pembelajaran yang bersaing atau kompetitif; 2) Pembelajaran perseorangan atau individual; 3) Pembelajaran yang responsive atau kooperatif (Salim dan Yusuf, 2009).

Filtrasi sebagian dari model pembelajaran yang diuraikan di atas sangat bergantung kepada: a) Kondisi atau kualifikasi kemampuan terhadap ABK, b) Kompetensi pendidik/guru; c) Banyaknya pendidik; d) Sarana-prasarana yang diperlukan kesediaannya. Metode pengorganisasian proses pembelajaran dipilah menjadi dua jenis, ialah: strategi atau metode makro dan mikro. Strategi atau metode makro: mengarah pada strategi untuk mengorganisasikan isi pembelajaran yang prosedur, konsep, dan prinsip. Strategi makro berhubungan dengan bagaimana cara memilih, membuat sintesis, menata urutan, serta rangkuman isi pembelajaran seperti konsep, prosedurdan prinsip yang saling berhubungan.

Sistematika urutan muatan mengarah pada urutan konsep-prinsip tertentu yang hendak dipelajari. Penyusunan sistesa mengarah pada keputusan mengenai bagaimana teknik atau cara menginstruksikan keterkaitan an tara konse dan prinsip. Membuatan rangkuman atau intisari mengarah pada keputusan mengenai bagaimana teknik cara melaksanakan tinjauan atau kajian ulang konsep, prinsip dan kaitan yang sudah dipelajari. Strategi atau metode penyampaian isi 
pembelajaran adalah komponen atau elemen variable strategi untuk melaksanakannya program proses pembelajaran. Ada dua minimal fungsi dari metode atau strategi menurut (Budiyanto, 2005) ialah: 1) Menyajikan muatan pembelajaran terhadap siswa; 2) Menyajikan data atau informasi yang dibutuhkan siswa untuk mempresentasikan performa atau kinerja, seperti latihan atau bimbingan serta tes.

Metode penyampaian meliputi guru, lingkungan fisik, bahan pembelajaran, serta kegiatan berkaitan dalam proses pembelajaran. Istilah lainnya, media adalah satu elemen atau komponen yang bermanfaat melalui strategi atau metode penyampaian proses pembelajaran. Oleh karena itu, ada tiga komponen yang penting diperhatikan di dalam membuat preskripsi metode atau strategi dalam penyampaian, mencakup: a) Media/perangkat pembelajaran; b) Interaksi/korelasi pengajar dengan perangkat/media; c) Desain atau format kegiatan pembelajaran. Media/perangkat pembelajaran ialah elemen penyampaian pesan kepada si pebelajar, baik itu orang, bahan ataupun alat. Terdapat lima teknik di dalam menginterpretasikan perangkat pembelajaran untuk kebutuhan mempreskripsikan metode atau strategi dalam penyampaian, ialah: 1) Level akurasi keterwakilan; 2) Level interaksi yang dapat dimunculkan; 3) Level kompetensi tertentu yang dimiliki; 4) Level motivasi atau dorongan yang bias ditekankan; 5) Level anggaran yang dibutuhkan. Interaktif siswa dengan perangkat/media ialah bagian atau elemen metode penyampaian yang mengarah pada program yang dilaksanakan oleh si pembelajar serta bagaimana peranan perangkat media di dalam merangsang atau mendorong aktivitas belajar. Kerangka kegiatan pembelajaran ialah bagian metode/strategi di dalam penyampaian yang mengarah pada pebelajar dalam kelompok besar, kecil, mandiri atau perseorangan.

\section{Strategi Pengelolaan}

Program pengelolaan pembelajaran ini ialah elemen variable strategi yang berhubungan bagaimana cara membenahi hubungan siswa dengan variable strategi pembelajaran lainnya. Metode pengambilan keputusan perihal skema atau metode penyampaian serta pengorganisasiannya mana yang dipergunakan selama dalam mekanisme pembelajaran. Ada empat pengategorian penting tentang variable metode atau strategi pengelolaan, ialah: 1) Perencanaan; 2) Pembuatan catatan atau notulen kemajuan proses belajar; 3) Pengelolaan atau manajemen motivasi; 4) Kontrol atau pengaturan belajar. Perencanaan penerapan strategi atau metode pembelajaran mengacu pada kapan serta berapa waktu suatu metode atau strategi pembelajaran, elemen suatu metode pembelajaran dipergunakan pada situasi proses pembelajaran. Membuat catatan atau notulen kemajuan proses belajar mengarah pada kapan serta berapa waktu penilaian hasil proses belajar dilaksanakan, dan bagaimana strategi prosedur penilaiannya tersebut. Pengelolaan atau manajemen motivasional mengarah pada cara yang dipergunakan untuk bagaimana meningkatkan motivasi proses belajar-pebelajar.

\section{KESIMPULAN}

Kurikulum yang umum bila digunakan untuk $A B K$ perlu penyesuaian sesuai dengan kebutuhan $A B K$, berupa pengurangan atau perampingan Kompetensi Dasar, 
sehingga menjadi kurikulum inklusi yang digunakan pada sekolah inklusi bagi ABK tingkat ringan dan sedang. Pada kurikulum inklusi penyesuian bukan saja pada pengurangan kompetensi dasar tetapi juga pada metode pembelajaran dan evaluasi hasil belajar. Hasil kurikulum ini beserta perangkatnya (pedoman) secara umum telah dipahami dan diterima dengan baik oleh kepala sekolah dan guru. Diharapkan kurikulum sekolah inklusi yang dikembangkan ini dapat membantu guru dan digunakan secara lebih luas pada sekolah inklusi lainnya guna memperlancar ketercapaian program pendidikan dasar wajib belajar bagi $A B K$ di seluruh Indonesia.

\section{REFERENSI}

Borg, W. R. \& Gall, M. D. (2003). Educational research: An introduction (7th ed.). New York: Longman, Inc.

Budiyanto. (2005). Pengantar pendidikan inklusi berbasis budaya lokal. Jakarta: Prenadamedia Grup.

Emawati, (2008). Mengenal lebih jauh sekolah inklusi. Pedagogik Jurnal Pendidikan, $5(1), 25-35$.

Friend, Marilyn \& Bursuck, D William. (2015). Menuju pendidikan inklusi. Yogjakarta: Pustaka Pelajar.

Hermanto. (2010). Penyelenggaraan pendidikan inklusif membutuhkan keseriusan manajemen sekolah. Jurnal Pendidikan Khusus, 6(1), 65-82.

Kadir, Abd. (2015). Penyelenggaraan sekolah inklusi di Indonesia.Jurnal Pendidikan Agama Islam, 3(1), 1-22.

Salim, Abdul \& Yusuf, Munawir. (2009). Pendidikan anak berkebutuhan khusus secara inklusif. Surakarta: Yuma Pustaka.

Skjorten, MD. (2001). Towards inclusion and enrichment, Artikel in Johnsen. Oslo: Unipubforlag.

Stainback, W. \& Sianback, S. (1990). Support networks for inclusive schooling: Independent integrated education. Baltimore: Brookes Publishing.

Sugiyono. (2017). Metode penelitian kuantitatif, kualitatif dan $R \& D$. Cetakan 23. Bandung: Alfabeta CV.

Sunardi. (2005). Kecenderungan dalam pendidikan luar biasa. Jakarta: Depdikbud. Vaughn. Bos \& Schumm. (2000). Adaptive mainstreaming. NY: John Wile. 